\title{
SIX NEW SPECIES OF ASPIDISTRA (RUSCACEAE) FROM NORTHERN VIETNAM
}

\author{
H.-J. TILLICH, L.V. AVERYANOV \& N.V. DZU \\ Ludwig-Maximilians-Universität München, Faculty of Biology, \\ Systematic Botany and Mycology, Menzingerstr. 67, 80638 München, Germany; \\ e-mail: hjtillich@lrz.uni-muenchen.de, av_leonid@mail.ru,vandu@netnam.vn
}

\section{SUMMARY}

Six species of Aspidistra Ker Gawl. (Ruscaceae) from Vietnam new to science are described. The total number of known Aspidistra species now increases to 90.

Key words: Convallariaceae, Ruscaceae, Aspidistra, Vietnam.

\section{INTRODUCTION}

The Southeast Asian genus Aspidistra Ker Gawl. of Ruscaceae s.l. (this family name has priority over Convallariaceae, see APG II (2003)) was notoriously overlooked for many decades. Aspidistras are at first glance inconspicuous members of forest undergrowth, but the diversity of flower types makes this genus one of the most spectacular

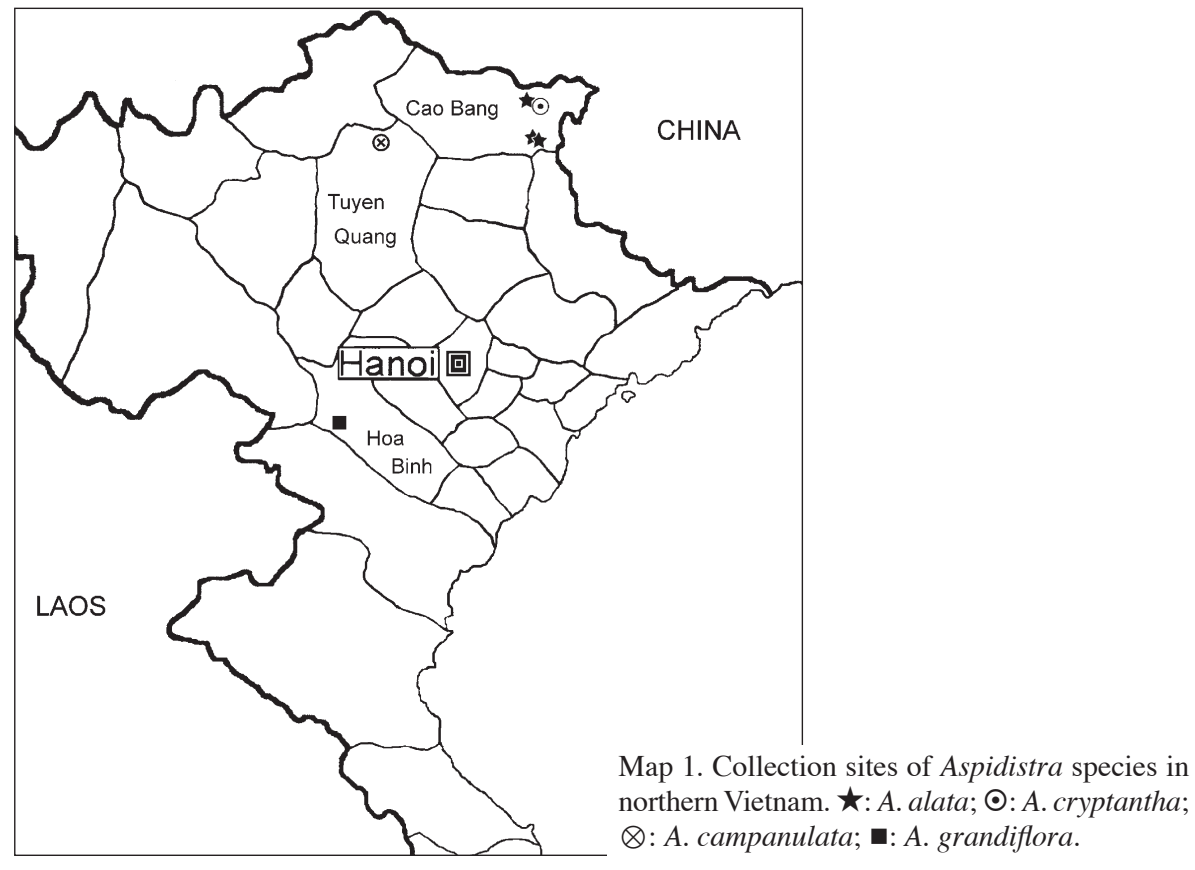


in Angiosperms (Lang et al., 1999; Li et al., 2000; Li, 2004; Tillich, 2005). Since about 1980, the number of known Aspidistra species is increasing rapidly, and only during the past three years 22 new species have been described (Li \& Wei, 2003; De Wilde \& Vogel, 2005; Tillich, 2005, 2006). In the course of ongoing investigation of the genus Aspidistra in Vietnam there arose the opportunity of studying herbarium material from the National Centre of Science and Technology Hanoi (HN) as well as the material from St. Petersburg (LE) and St. Louis (MO). This resulted in the identification of more new species collected in northern Vietnam (Map 1). Unfortunately, a lot of herbarium specimens are prepared in only vegetative stages; but without well-prepared flowers a determination of species is mostly impossible. The best way is to take the plants in cultivation under permanent observation to detect the flowers, which mostly develop at ground level and are more or less hidden below the leaves (Tillich, 2005; De Wilde \& Vogel, 2005). Herbarium specimens then should include well-prepared flowers and at the best also colour photos. Including the following new species, we currently have knowledge of 90 Aspidistra species.

\section{DESCRIPTION OF SPECIES}

\section{Aspidistra alata Tillich, spec. nov. - Fig. 1}

Aspidistrae xiliensis Y. Wan \& X.H. Lu similis, sed laminis linearibus 50-60 cm longa $2-3 \mathrm{~cm}$ lata, perigonii lobis ligulatis, staminibus tubi basi insertis differt. - Typus: L.V. Averyanov et al. VH 2456 (holo HN, photo M; iso LE), Vietnam, Prov. Cao Bang, Distr. Tra Linh, Subdistr. Quoc Toan, near Thang Heng Lake, alt. 600-700 m, 04.01.1996.

Perennial herb. Rhizome creeping, 5-6 mm diam., densely covered with fibrous remnants of cataphylls. Leaves distally crowded, $80-100 \mathrm{~cm}$ long, petiole $15-20 \mathrm{~cm}$, lamina linear, $60-80$ by $2.5-3.5 \mathrm{~cm}$, basally gradually tapering to petiole, in herbaria typically blackish brown, with a yellow prominent midrib at lower surface. Flowers solitary, peduncle decumbent, 5-7 cm, with two bracts halfway and one at the base of the flower. Perigone dirty green-violet to dirty reddish; tube urceolate, $8-10 \mathrm{~mm}$ long, diam. at lower third 10-12 mm, distally decreasing to 5-6 mm; lobes 6, ligulate with rounded tips, reflexed, 8 by $4 \mathrm{~mm}$, each with 4 thin, parallel keels $1.5-1.8 \mathrm{~mm}$ high, keels distally fusing to each other and basally running to the base of the tube. Anthers 6, sessile, ovoid, 1.2 by $0.8 \mathrm{~mm}$, closely attached to the pistil base. Pistil mushroom shaped, ovary inconspicuous, style cylindrical, $2 \mathrm{~mm}$ long, stigma hemispherical, $5 \mathrm{~mm}$ diam., upper surface with irregular furrows similar to a brain surface.

Distribution - The species is known from three places in Province Cao Bang which is directly adjacent to the Chinese Province Guangxi, the diversity centre of the genus. It may occur also in Guangxi as well as some species from southern Guangxi can be expected also in Cao Bang. However, recently only one species, A. dolichathera $\mathrm{X} . \mathrm{X}$. Chen, is documented in both provinces.

Habitat \& Ecology - The species grows in primary evergreen and secondary semideciduous forests on steep slopes of remnant limestone mountains. In some places very common.

Etymology - From Latin alatus = winged, referring to the prominent thin keels (wings) on perigone lobes. 


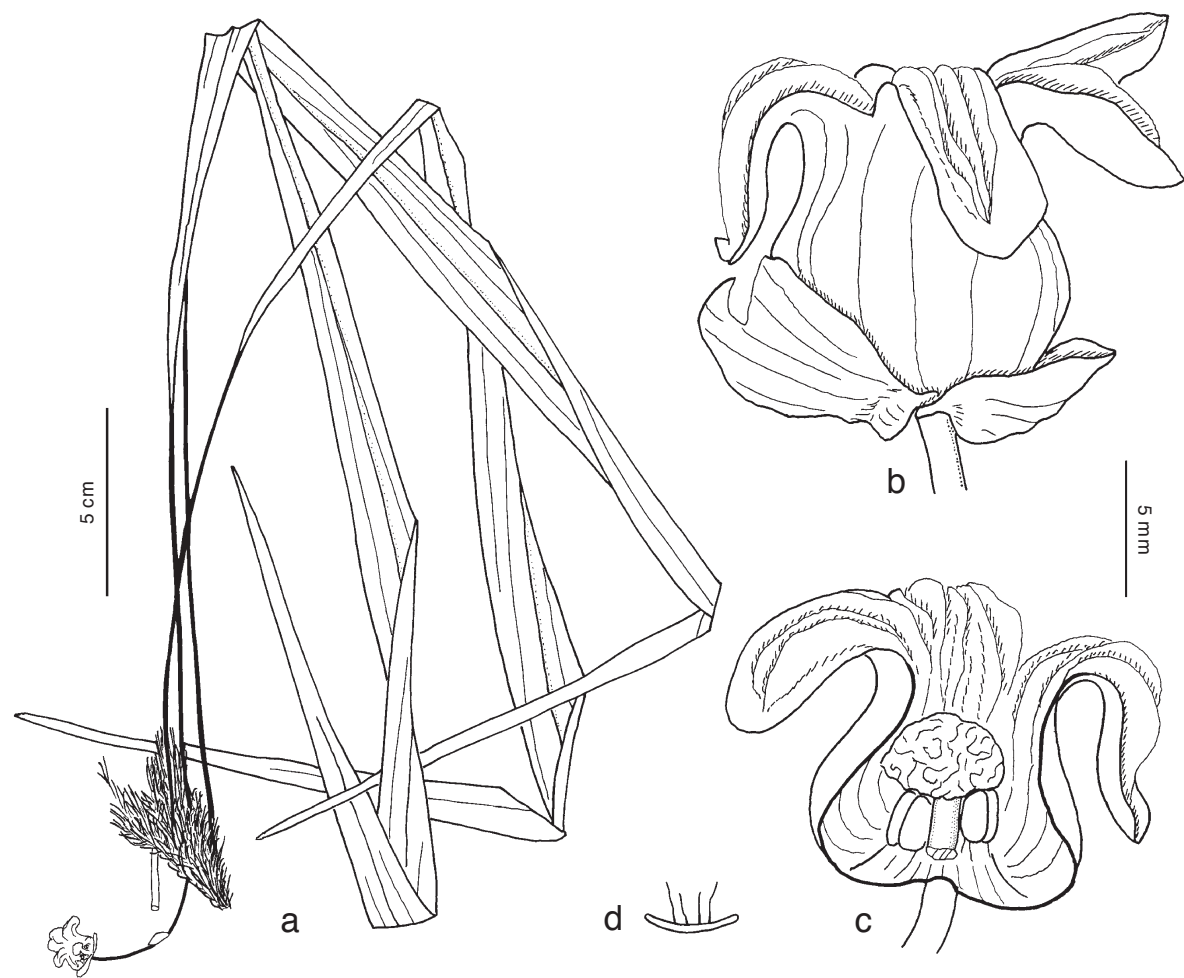

Fig. 1. Aspidistra alata Tillich. a. Habit; b. flower; c. perigone in longitudinal section, the frontal stamen detached; d. lobe in cross section to show the position and height of keels (all from type specimen).

Additional specimens:

Averyanov et al. CBL 840 (HN, MO), Vietnam, Prov. Cao Bang, Distr. Thach An, municipality Van Trinh, c. $39 \mathrm{~km}$ SSE of Cao Bang Town, 22 ${ }^{\circ} 21^{\prime} \mathrm{N}, 106^{\circ} 27^{\prime} \mathrm{E}, 600 \mathrm{~m}$ alt., 03.12.1998; $\mathrm{Av}$ eryanov et al. CBL 879 (HN, MO), Vietnam, Prov. Cao Bang, Distr. Thach An, municipality Thuy Hung, vicinity of village Na Hit, c. $27 \mathrm{~km} \mathrm{SE}$ Cao Bang Town, $22^{\circ} 30^{\prime} \mathrm{N}, 106^{\circ} 27^{\prime} \mathrm{E}, 450-500 \mathrm{~m}$ alt., 04.12.1998.

2. Aspidistra campanulata Tillich, spec. nov. - Fig. 2, 4i

Aspidistrae dolichantherae X.X. Chen similis, sed laminis $13-15 \mathrm{~cm}$ longis $3.5-5 \mathrm{~cm}$ latis, perigonio campanulato lobis angusta triangularibus, $10 \mathrm{~mm}$ longis $3 \mathrm{~mm}$ latis differt. - Typus: P.K. Loc, N.X. Tam, L.V. Averyanov HAL 211 (holo HN, photo M), Vietnam, Prov. Tuyen Quang, Distr. Na Hang, Xuan Tam municipality, near village Ban Cai, alt. 450-500 m, 22.03.2001.

Perennial herb. Rhizome creeping epigeously, 3-4 mm diameter. Leaves 5-10 mm apart, petiole c. $7 \mathrm{~cm}$ long, gracile, lamina ovate-narrowly ovate, distally tapering into a long tip, $13-15$ by $3.5-5 \mathrm{~cm}$. Flowers solitary, peduncle stiff upright, very thin, 4-6.5 cm long, with two basal bracts and one adjacent to the flower; flower position horizontally or obliquely upright, with very pleasant fragrance. Perigone campanulate, 


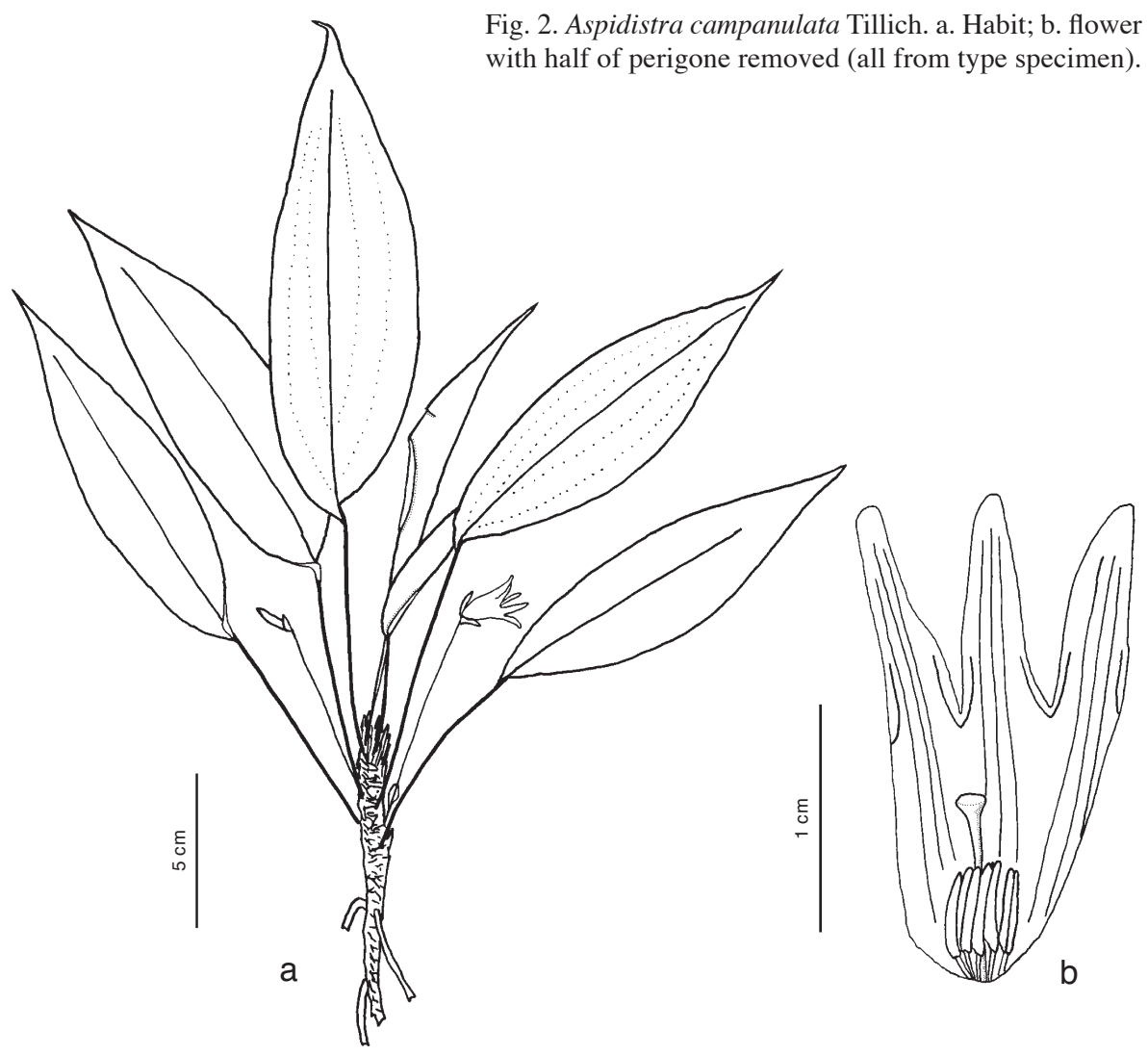

white, tube $10 \mathrm{~mm}$ long and wide, lobes 6 , narrow triangular with rounded tips, $10 \mathrm{~mm}$ long and 2.5-3 mm wide at base; tube wall and lobes thin, lobes without keels, but with three nerves running down to the tube base and additionally, at each side a short submarginal vein basally fusing with that of the adjacent lobe. Stamens 6, at the very base of the tube, closely surrounding the style, filaments $1-1.5 \mathrm{~mm}$, anthers lineate, 2.5 by $0.5 \mathrm{~mm}$; pistil very slender, ovar inconspicuous, style c. $8 \mathrm{~mm}$ long, stigma somewhat widened, 1-1.2 mm diameter.

Distribution - The species is known from the type locality only, where it is very common.

Habitat \& Ecology - The species grows in primary broad-leaved evergreen forests on very steep slopes of highly eroded remnant limestone ridges.

\section{Aspidistra cryptantha Tillich, spec. nov. - Fig. 3}

Aspidistrae minutiflorae Stapf similis, sed laminis lanceolatis, ca. $20 \mathrm{~cm}$ longis 5-6 cm latis, perigonio 6-7 mm diametro, stigmate trilobo, lobis apice lobulo inflexo differt. - Typus: L.V. Averyanov et al. VH 2460 (holo HN, photo M), Vietnam, Prov. Cao Bang, Distr. Tra Linh, Subdistr. Quoc Toan, near Thang Heng lake, in environs of Thang Hen and Lung Tao villages, alt. 600-700 m, 04.01.1996. 


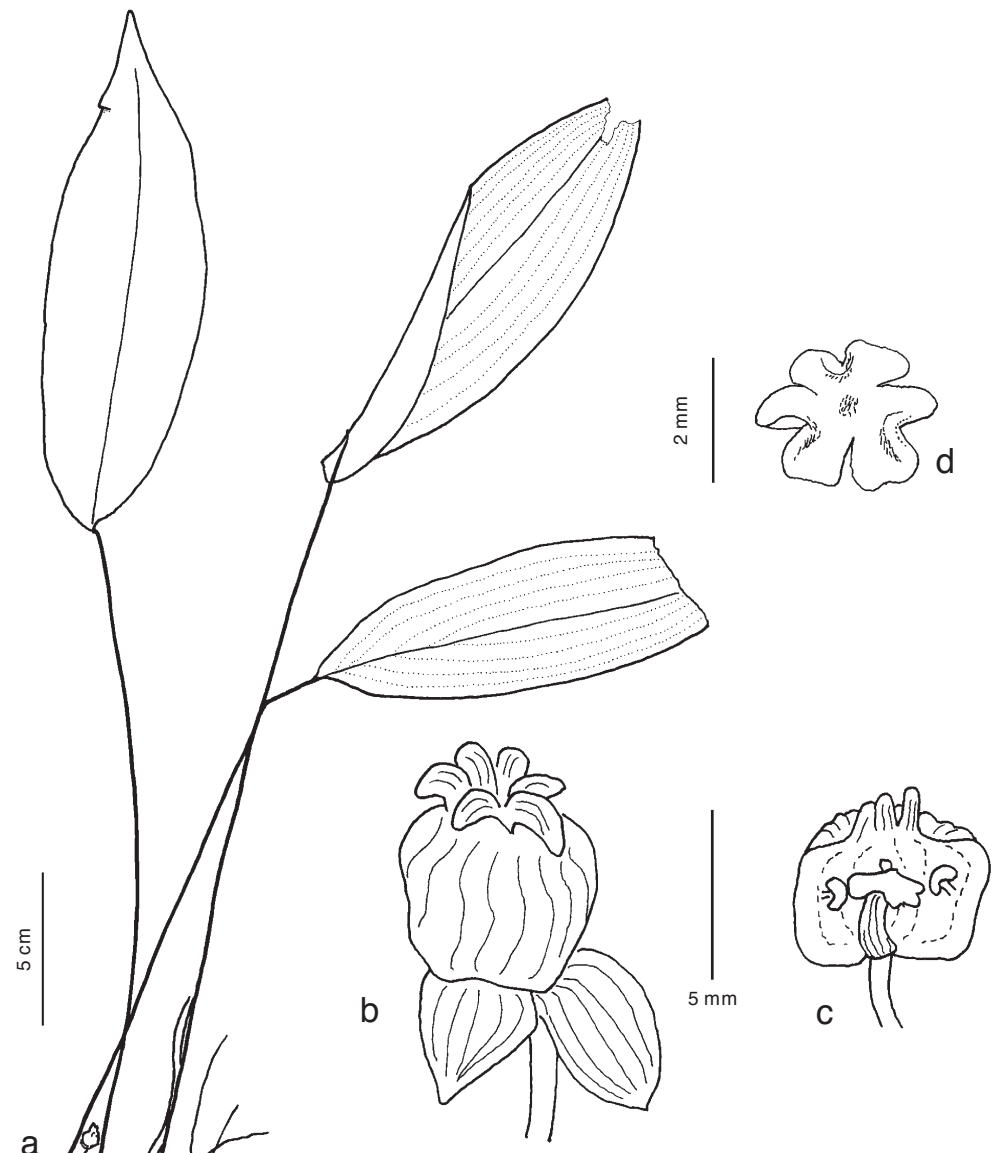

Fig. 3. Aspidistra cryptantha Tillich. a. Habit; b. flower; c. flower with half of perigone removed; d. stigma in upper view (all from type specimen).

Perennial herb. Rhizome creeping, $5 \mathrm{~mm}$ diam.; cataphylls short lived, leaving fibrous remnants at base of youngest leaves. Leaves delicate, 1-1.5 cm apart, petiole 18-25 $\mathrm{cm}$, lamina ovate-lanceolate, acuminate, $17-20$ by $5-6 \mathrm{~cm}$, basally rounded or broadly cuneate, with numerous small white spots, nerves in dried specimen at lower surface distinctly yellowish, prominent, 4-6 stronger veins at each side, between each of them 7 smaller veins. Peduncle 1-2 cm, ascending, one scale adjacent to flower base, one somewhat below. Perigone tube subgloboid, greatest 6-7 $\mathrm{mm}$ diam., distal opening 2-3 mm, lobes 6, reflexed, ovate-lanceolate, $1.5-2$ by $1 \mathrm{~mm}$, with 2 keels. Anthers 6, subsessile, at middle height of tube, ovoid, c. $1 \mathrm{~mm}$ long. Pistil table-shaped, ovary indistinct, style cylindrical, 2-3 mm long, stigma flat, 2-3 mm diam., 3-lobed, each lobe with distal lobulum inflexum.

Distribution - The species is known from the type locality only.

Habitat \& Ecology - The species grows in evergreen forests on slopes of remnant limestone mountains between $600-800 \mathrm{~m}$, very common at 700-800 m. 

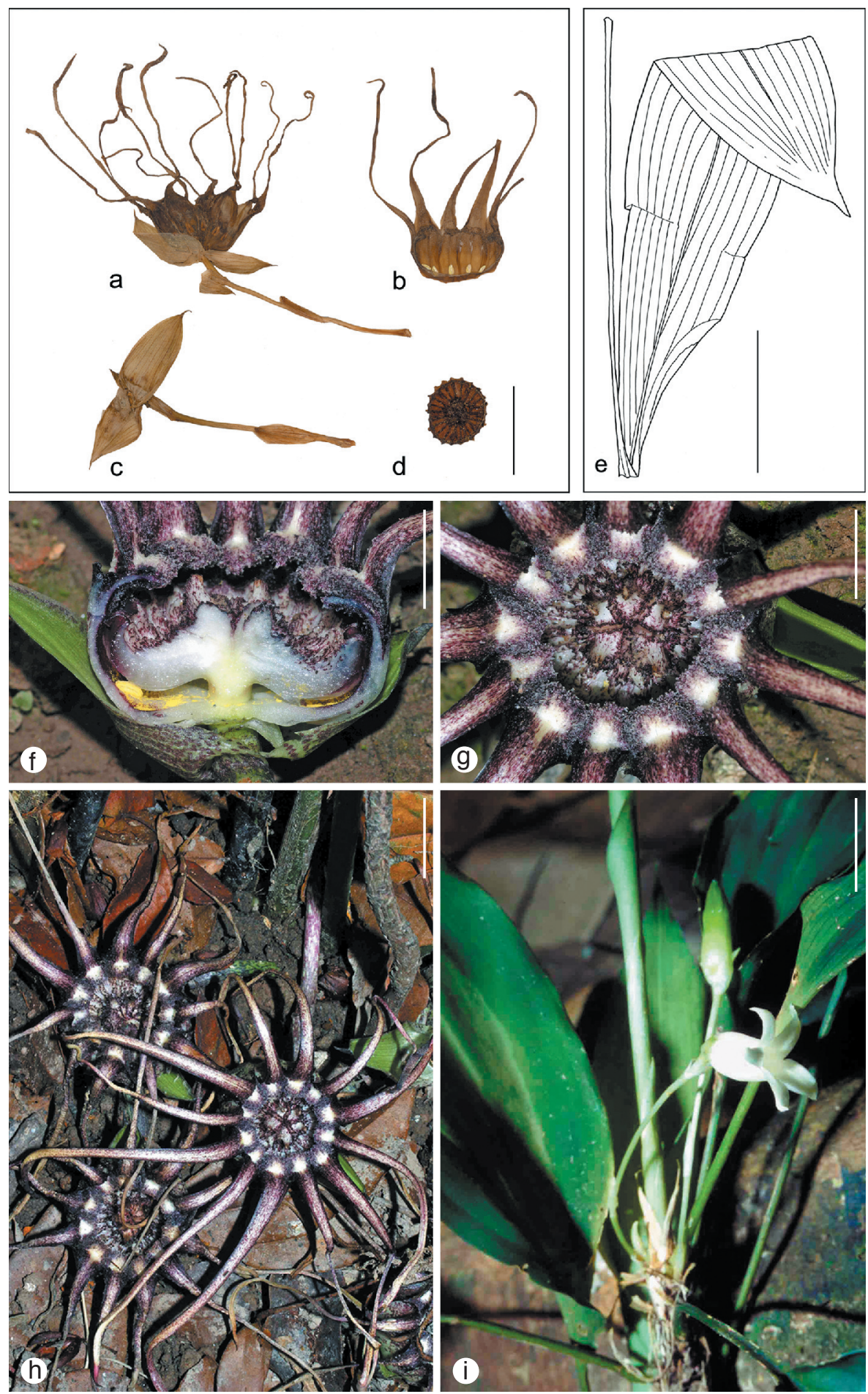
4. Aspidistra grandiflora Tillich, spec. nov. - Fig. 4a-h

Aspidistrae superbae Tillich similis, sed perigonio ca. $30 \mathrm{~mm}$ diametro, lobis (11 vel) 12 anguste linearibus 50-60 mm longis, stigmate margine 22-24 dentato differt. - Typus: D. Harder et al. DKH 8123 (holo LE; iso M), Vietnam, Prov. Hoa Binh, Distr. Mai Chau, municipality Van Mai, at Highway 7, alt. 300-350 m, 12.12.2002.

Perennial herb. Rhizome creeping. Leaves solitary, petiole c. $30 \mathrm{~cm}$, lamina narrowly obovate, c. 50 by $11 \mathrm{~cm}$, basally narrowly cuneate, gradually tapering to petiole, widest in upper third. Peduncle c. $7 \mathrm{~cm}$ long, decumbent, with two scales along the axis 20 by $7 \mathrm{~mm}$, two ovate-acuminate bracts at the base of the perigone, 25 and $35 \mathrm{~mm}$ long. Flowers solitary or in groups of 2 or 3 , perigone tube depressed urceolate, twice as wide as high, c. $30 \mathrm{~mm}$ diam., lobes (11 or) 12, narrow lineate with wider base, $50-60 \mathrm{~mm}$ long, whitish and densely purplish mottled, each lobe with basal white appendage with verrucose dark purple margin, appendages protruding horizontally over tube opening similar to an iris diaphragm reducing the opening to $15-18 \mathrm{~mm}$. Stamens (11 or) 12 , anthers subsessile, at periphery of tube base, ovoid, c. $3 \mathrm{~mm}$ long. Ovary indistinct, style 3 by $5 \mathrm{~mm}$, stigma disc-shaped, c. $8 \mathrm{~mm}$ thick, the central part white with 5 purple radial ribs, peripherical with $22-24$ fine teeth.

Distribution - The species is known from the type locality only.

Habitat \& Ecology - The species grows in primary very dry broad-leaved lowland forests on rocky, karstic limestone outcrops with deep fissures, occasional.

\section{Aspidistra recondita Tillich, spec. nov. - Fig. 5}

Aspidistrae locii Arnautov \& Bogner similis, sed rhizome repenti, perigonio erecto ovoideo 9-10 mm diametro differt. - Typus: 1111 ep (s.l., n.v.), (holo HN, photo M), 15.11.71.

Perennial herb. Rhizome creeping, 5-6 mm diameter. Leaves 1-1.5 cm apart, petiole strong, $25-35 \mathrm{~cm}$, lamina narrowly ovate, distinctly asymmetrical, c. 30 by $6 \mathrm{~cm}$, base cuneate, each side of lamina with 30-40 secondary veins of nearly equal size. Peduncle slender, decumbent, $2-3 \mathrm{~cm}$, with 2 scales along the axis and 2 broadly ovate scales embracing the flower. Perigone ovoid, 12 by $9-10 \mathrm{~mm}$, without lobes, distal opening 1.5-2 mm. Stamens 6 , at basal third of tube, sessile, anthers 3 by $1.5 \mathrm{~mm}$. Pistil mushroom shaped, ovar indistinct, style c. $3 \mathrm{~mm}$, stigma hemispherical, $6 \mathrm{~mm}$ wide and high.

Etymology - From Latin reconditus $=$ hidden, referring to the sexual organs completely hidden inside the ovoid perigone with an only very small distal opening.

Note - The plant was collected somewhere in North Vietnam. It was determined as A. lurida Ker Gawl. by Nguyen Thi Do at 20.04.1993. The label (Flora Vietnamica) gives no information concerning collection site nor collector's name. There is no information about its habitat or ecological preferences.

Fig. 4. a-h: Aspidistra grandiflora Tillich. a. Flower with peduncle and bracts; b. internal view of part of perigone; c. peduncle with flower removed to show the shape of flower subtending bracts; d. stigma in upper view; e. leaf; f. flower in longitudinal section; g. flower centre in upper view; h. flowers in original position in the type habitat (a-e from type specimen). - i: Aspidistra campanulata Tillich. Photos f-i: L.V. Averyanov. Scale bars: a-d, h: $3 \mathrm{~cm}$; e: $10 \mathrm{~cm}$; f, g, i: $1 \mathrm{~cm}$. 


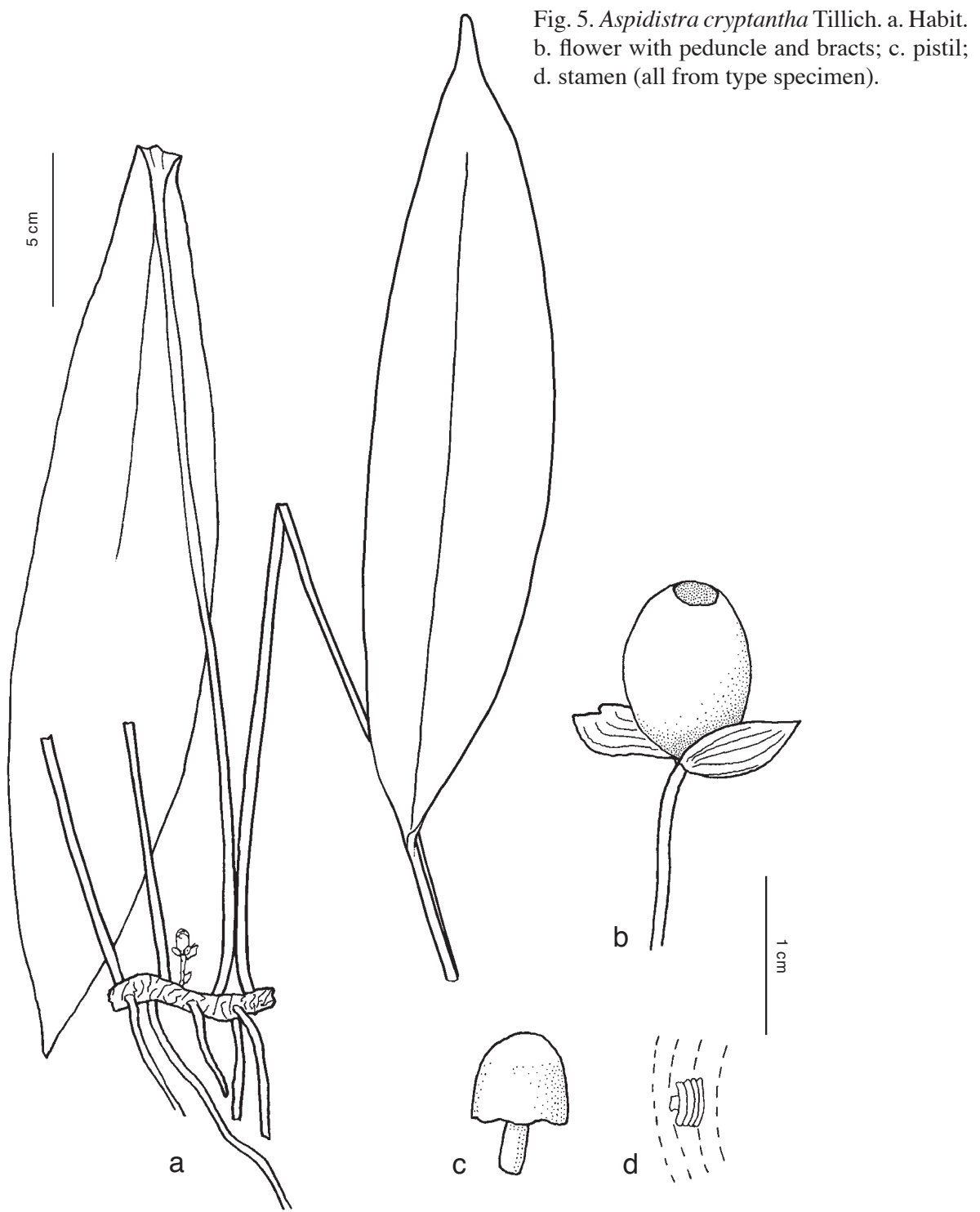

6. Aspidistra umbrosa Tillich, spec. nov. - Fig. 6

Aspidistrae saxicolae Y. Wan similis, sed petiolis $30-35 \mathrm{~cm}$ longis, laminis ca. $30 \mathrm{~cm}$ longis ca. $10 \mathrm{~cm}$ latis, perigonii lobis ligulatis supra bicarinatis differt. - Typus: 1159 ep (s.l., n.v.), (holo HN, photo M), 22.11.71.

Perennial herb. Rhizome creeping, $5 \mathrm{~mm}$ diameter. Leaves $1.5-2.5 \mathrm{~cm}$ apart, petiole strong, (15-)30-35 cm, lamina obovate-acuminate, widest in upper half, 30 by 10-11 $\mathrm{cm}$. Peduncle $0.2-0.5 \mathrm{~cm}, 2$ bracts adjacent to perigone, densely embracing perigone tube. Perigone campanulate, purple, $15 \mathrm{~mm}$ long, tube $10 \mathrm{~mm}$ long, $7 \mathrm{~mm}$ diam., lobes 6 , ligulate with rounded tips, somewhat patent, $4-5$ by $2 \mathrm{~mm}$, with 2 low median keels 
Fig. 6. Aspidistra umbrosa Tillich. a. Habit;

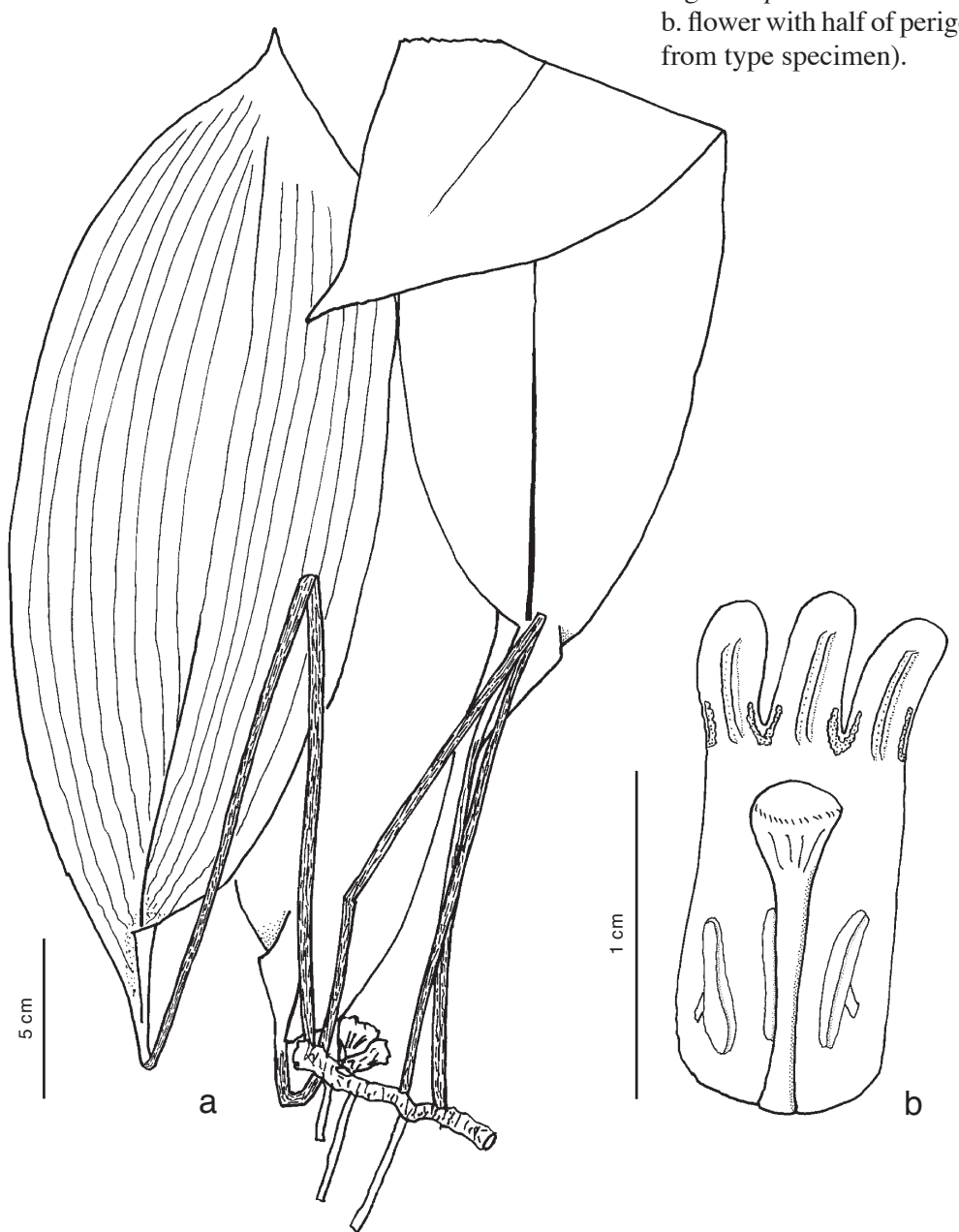

and at the basal margins with verrucose keels in contact to that of the adjacent lobe. Stamens 6, anthers subsessile, linear, at lower third of tube wall, 4.5 by $1.5 \mathrm{~mm}$. Pistil slender, $10 \mathrm{~mm}$ long, ovary inconspicuous, style distally gradually widened to stigma, stigma $3 \mathrm{~mm}$ diam., subrotundate, surface smooth.

Note - The plant was collected somewhere in North Vietnam. It was determined as 'Aspidistra sp. 2' by Nguyen Thi Do at 15.05.2000. The label (Flora Vietnamica) gives no information concerning collection site nor collector's name. There is no information about its habitat or ecological preferences.

\section{ACKNOWLEDGEMENTS}

The authors are grateful to the curators of the herbaria HN, LE and MO, to Nick Turland (St. Louis) for helpful information and Dieter Podlech (Munich) for assistance in designing the Latin diagnoses. 


\section{REFERENCES}

APG II. 2003. An update of the Angiosperm Phylogeny Group classification for the orders and families of flowering plants: APG II. Bot. J. Linn. Soc. 141: 399-436.

De Wilde, W.J.J.O. \& A. Vogel. 2005. A new species of Aspidistra (Convallariaceae) from Perak, Peninsular Malaysia. Folia Malaysiana 6: 125-130.

Lang, K.Y., G.-Z. Li, Y. Liu, Y.-G. Wei \& R.-X. Wang. 1999. Taxonomic and phytogeographic studies on the genus Aspidistra Ker Gawl. (Liliaceae) in China. Acta Phytotax. Sin. 37: 468-508.

Li, G.-Z. (ed.). 2004. The genus Aspidistra. Guangxi Science \& Technology Publishing House.

Li, G.-Z., K.-Y. Lang, R. -X. Wang \& Y.-G. Wei. 2000. On the trends of morphological differentiation and a new system of classification in Chinese Aspidistra Ker Gawl. (Liliaceae). Guihaia 20: 201-217.

Li, G.-Z. \& Y.-G. Wei. 2003. Two new species of the Aspidistra Ker Gawl. (Liliaceae). Acta Phytotax. Sin. 41: 381-386.

Tillich, H.-J. 2005. A key for Aspidistra (Ruscaceae), including fifteen new species from Vietnam. Feddes Repert. 116: 313-338.

Tillich, H.-J. 2006. Four new species of Aspidistra Ker Gawl. (Ruscaceae) from China, Vietnam and Japan. Feddes Repert. 117: 139-145. 